\title{
Effect of aeration on growth and production of fish in intensive aquaculture system in earthen ponds
}

\author{
T. Sultana*, M. M. Haque, M. A. Salam and M. M. Alam \\ Department of Aquaculture, Bangladesh Agricultural University, Mymensingh-2202, Bangladesh \\ *E-mail: tanjin.bau@gmail.com
}

\begin{abstract}
An experiment was conducted to assess the effect of aeration using blower on growth and production of tilapia (Oreochromis niloticus) in intensive aquaculture system in six (6) earthen ponds at BAU campus, Mymensingh from May to September, 2016. Treatment $1\left(T_{1}\right)$ with 3 aerated ponds and Treatment $2\left(T_{2}\right)$ with 3 non-aerated ponds were designed with similar stocking density (300/decimal) of tilapia. Oxygen supply was ensured by blower for 9 hours daily when oxygen depletion occurs in pond water. Fish growth, pond water and soil quality parameters were sampled and assessed. The DO content in the aerated ponds was higher $(7.23 \mathrm{mg} / \mathrm{l})$ from the beginning to the end of experiment compared to non-aerated ponds $(2.33 \mathrm{mg} / \mathrm{l})$. There were significant differences $(p<0.05)$ of $\mathrm{DO}$ content between two treatments at first and last sampling stages. The higher length $(15.64 \pm 1.56 \mathrm{~cm})$ and weight gain (143.36 $\pm 39.33 \mathrm{gm})$, higher SGR (\% per day) for tilapia was $(2.54 \pm 0.00)$ found in $\mathrm{T}_{1}$ compared to $\mathrm{T}_{2}(2.42 \pm 0.00)$ with significant differences $(\mathrm{p}<0.05)$ between two treatments. In addition, the higher production of tilapia was obtained in $\mathrm{T}_{1}$ (9581.87 $\pm 0.00 \mathrm{~kg} / \mathrm{ha} / 100$ days) compared to $\mathrm{T}_{2}(6490.80 \pm 0.00 \mathrm{~kg} / \mathrm{ha} / 100$ days). The average phytoplankton production was relatively higher in $\mathrm{T}_{2}$ and conversely zooplankton abundance was higher in $\mathrm{T}_{1}$ without any significant differences ( $p>0.05$ ) between the treatments for the abundances of various groups of phytoplankton and zooplankton. Different water quality parameters were found with the better range in aerated ponds. Various intrinsic relationships between DO and other water quality and weather parameters showed that DO content had negative relationships with rainfall, air pressure and humidity but the relationships were not statistically significant. Moreover, different soil quality parameters of pond sediments were found in ideal range for fish culture in both treatments. These results suggest that aeration can be a potential mechanism of aqua-farming to enhance the growth and production of tilapia and DO content in pond water synchronizing other water quality parameters in ponds.
\end{abstract}

Keywords: Intensive aquaculture, Aeration, Dissolved oxygen, Weather parameters, Growth performance

\section{Introduction}

Aquaculture is the fastest growing animal based food-producing sector, particularly in developing countries like Bangladesh and its production contributes to the livelihoods, employment and also fulfills the nutritional demand for millions of people. Bangladesh has achieved $6^{\text {th }}$ position among the world's major aquaculture producing countries (FAO, 2016) and the total production of fish is around 3.6 million MT in 2014-2015, of which inland fisheries contributed $83.71 \%$ comprising $55.93 \%$ from aquaculture and $27.79 \%$ from capture fisheries (DoF, 2016). Any effort to increase animal protein production must be concentrated on aquaculture, since capture fisheries from open water bodies is stagnating due to declining open water resources. In Bangladesh, land area is declining with increasing population and the competition of aquaculture with other agricultural sectors is increasing in the context of land and water use. Therefore, intensive aquaculture is growing to enhance national fish production in the context of population growth and declining land resource that is required to construct ponds. Moreover, fish productions per unit area are much higher in intensive aquaculture system compared to semi-intensive and extensive system. Therefore, to fulfill the animal protein demand for teeming population in Bangladesh intensive fish culture system may be the alternative to enhance fish production since fish contributes about $60 \%$ of animal protein to our daily food (DoF, 2016).

Since in intensive aquaculture system, ponds are heavily stocked with fish as well as with high feed supply and in these artificially fed fish ponds, many problems like organic pollution, deficiency of oxygen, increased level of free carbon dioxide and total increase in ammonia-nitrogen, nitrite-nitrogen ratio are frequently occurring. However, the problem of oxygen depletion in rearing of freshwater fish species is a major threat and main limiting factor in intensive aquaculture because it leads to hypoxia which affects 
fish growth, food conversion levels and feeding efficiency etc. (Mallya, 2007) and fish always show high feed efficiency when they are fed at required DO in water (Boyd, 1998). The present study has taken tilapia as an experimental species for investigation the impacts of DO on tilapia's growth and production which is sensitive to the availability of DO in the water body as reported by Abdel-Tawwab et al. (2014). Along with the deficiency of DO content in water, another major problem in intensive aquaculture system is the presence of high concentrations of nutrients, especially phosphorus, ammonia, nitrite and nitrate. High concentrations of these nutrients can lead to excessive phytoplankton growth (phytoplankton bloom) and deterioration of pond water quality (Gilbert et al., 2001).

In the recent years, the marketing of aquaculture drugs and chemical has been increased and the use of different oxygen enhancing chemicals which has already been reported to exert negative impact on fish growth. Moreover, different algaecides are available in the market to control phytoplankton bloom in such ponds. Algaecide treatments temporarily rid the pond of phytoplankton however in almost all cases phytoplankton re-growth occurs (Le Jeune et al., 2006) and then repeated treatment is needed but is expensive. Even very low concentrations of copper sulfate may kill the zooplankton (grazers), leading to an even greater 'rebound' of phytoplankton biomass once the chemical leaves the system (Cooke and Kennedy, 2001). Considering the negative impacts of different chemicals in terms of enhancing DO content, reducing excessive phytoplankton growth in pond water and improving aquatic environment by keeping different water quality parameters in suitable range for fish growth, aeration can be the alternative and efficient way to get rid of deficiency of oxygen and organic pollution in intensive aquaculture systems (Agarwal, 1999; Boyd, 1995) and artificial aeration has been proposed as an alternative to the use of toxic algaecides. Moreover, emergency aeration is the best technique for preventing fish kills during $\mathrm{DO}$ crisis since aeration is the dissolution of oxygen $\left(\mathrm{O}_{2}\right)$ from the atmosphere $\left(21 \% \mathrm{O}_{2}\right)$ into water (Boyd, 1998; Swingle, 1968, Grizzel et al. 1969; Mayer and Eschmeyer, 1973).

Therefore, in the present study, a blower machine (Air Compressor) has been used for oxygen supply in intensive aquaculture ponds and the use of such type of blower is cost effective as reported by previous study and has a long term positive effects on fish growth and production. Considering the above context, the present study was carried out to determine the effect of aeration using blower on DO content in pond water, growth and production of fish, on different water and soil quality parameters, and to explore the relationship between water quality, with special emphasis on DO and weather parameters.

\section{Materials and Methods}

\section{Location of the study site and experimental design}

The experiment was conducted in the ponds situated at the campus of Bangladesh Agricultural University (BAU), Mymensingh during May to September 2016 (Fig. 1). For the experiment, two treatments with three replications were designed namely $T_{1}$ and $T_{2}$ with similar stocking density (300/decimal) of tilapia fry ( $0.4 \mathrm{~g}$ initial weight) and three ponds in $\mathrm{T}_{1}$ were treated with aeration through using blower and the rest three ponds in $\mathrm{T}_{2}$ were non-aerated. Following pond preparation, a blower machine (Air compressor, Model: VB-125G) was installed in the experimental pond for aeration three times daily and for three hours each time (11 pm-2 am, 3 am-6 am and 9 am-12 pm) generally when oxygen depletion occurs in pond water. Moreover, the average area of pond was 1.00 decimal for all treatments with an average depth of $1 \mathrm{~m}$. 


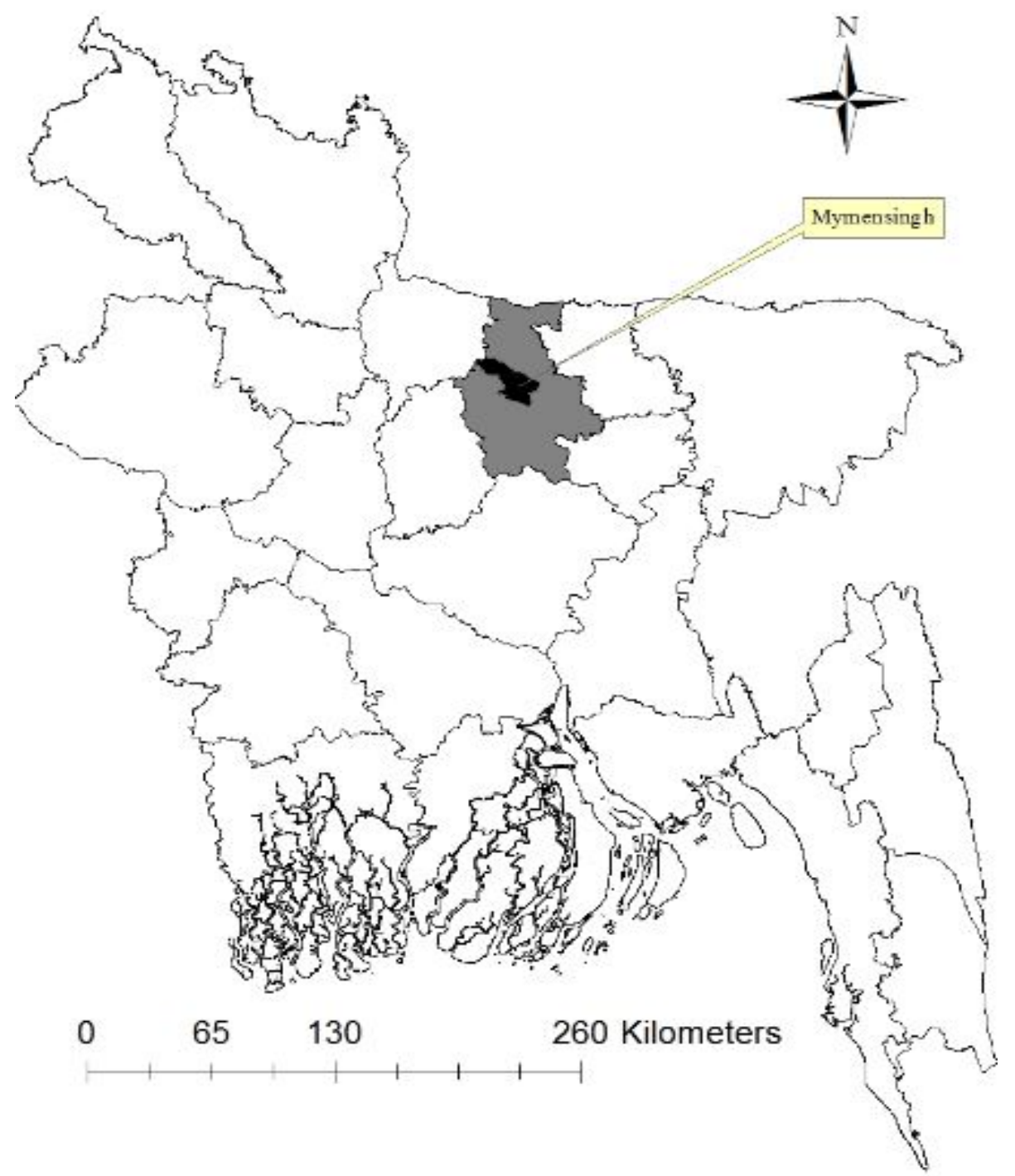

Fig. 1. Map of Bangladesh showing the study site at BAU campus in Mymensingh

\section{Study of growth parameters of fish}

For evaluating the growth of fish, different growth parameters such as length gain $(\mathrm{cm})$, weight gain $(\mathrm{g})$, percent (\%) weight gain, specific growth rate (SGR \% per day), and production (kg/ha/100 days) were taken into consideration and were measured using the following formula. The length and weight of fish were measured using centimeter scale and electric balance (Model: HKD-620AS-LED) in grams.

Weight gain $(\mathrm{g})=$ Mean final weight $(\mathrm{g})$ - Mean initial weight $(\mathrm{g})$

Percent weight gain $=\frac{\text { Mean final weight }(\mathrm{g})-\text { Mean initial weight }(\mathrm{g})}{\text { Mean initial weight }(\mathrm{g})} \times 100$

SGR (\%) per day $=\frac{\log W_{2}-\log W_{1}}{T_{2}-T_{1}} \times 100$

Production $=$ No. of harvested fishes $\times$ average final weight increase of fishes 


\section{Study of water quality parameters}

Different physico-chemical parameters including DO was measured at seven days interval using both $\mathrm{HACH}$ test kit (FF-1A, cat. No. 2430-02) and DO meter (Model: DO-5509). Other water quality parameters including water temperature (using celsius thermometer), $\mathrm{pH}$, ammonia, and nitrite were measured using $\mathrm{HACH}$ test kit (FF-1A, Cat. No. 2430-02) at 15 days interval during the study period in the Aquaculture Laboratory under the Department of Aquaculture, BAU, Mymensingh.

\section{Study of plankton as biological parameter}

Plankton population of ponds water such as phytoplankton and zooplankton were identified to generic level and counted using Sedgwick-Rafter Counting Cell (S-R cell) under a compound binocular microscope (Model: Primo Star HAL/LED microscope) at the mid and end of the trial in the Limnology Laboratory under the Department of Fisheries Management, BAU, Mymensingh. Moreover, plankton population (cells/L) was determined by using the formula of Rahman (1992).

\section{Study of chemical parameters of pond bottom soil}

For the measurement of different chemical parameters such as, soil $\mathrm{pH}$, organic matter, total nitrogen, available phosphorus, available potassium of pond bottom soil, soil samples were collected before the beginning and after end of trial using soil core sampler (agar) from the experimental ponds. Following air drying of soil samples in brown paper, these samples were then analyzed using different standard methods in Humboldt Soil Testing Laboratory under the Department of Soil Science, BAU, Mymensingh.

\section{Study of relationship between major water quality and weather parameters}

Different weather parameters including air temperature, rainfall, air pressure and humidity were recorded from the study site throughout the study period. Therefore, a real-time mini weather station (Vantage PRO 2) was established at the rooftop of the Faculty of Fisheries, BAU in order to facilitate this activity. The 24 hours data of different weather parameters were recorded using computer connected data logger.

\section{Data processing and analysis}

The recorded data were entered into the spreadsheet of MS Excel 2007 and then summarized properly before statistical analysis. An independent sample T-test was done to assess the differences between $T_{1}$ and $T_{2}$ in terms of DO content, fish production, water quality parameters, plankton abundance and different chemical parameters of pond bottom soil. Moreover, correlation analysis was done to determine the positive or negative relationships between water quality and weather parameters. The inferential Ttest and bivariate correlation analysis was carried out using SPSS (Statistical Package for Social Sciences) version 16.

\section{Results}

\section{Dissolved oxygen (DO) content}

The mean values of the DO content of the pond water were $6.24 \pm 1.14$ and $5.54 \pm 1.43 \mathrm{mg} / \mathrm{l}$ in $T_{1}$ and $T_{2}$, respectively. There were significant differences $(p<0.05)$ of DO between two treatments at first and last sampling stages. The DO content in the ponds of $T_{1}$ was higher from the beginning to the end of experiment except at one stage of sampling (31-May-16) where mean values of dissolved oxygen were similar in both treatments possibly due to technical problem of blower (Fig. 2). 


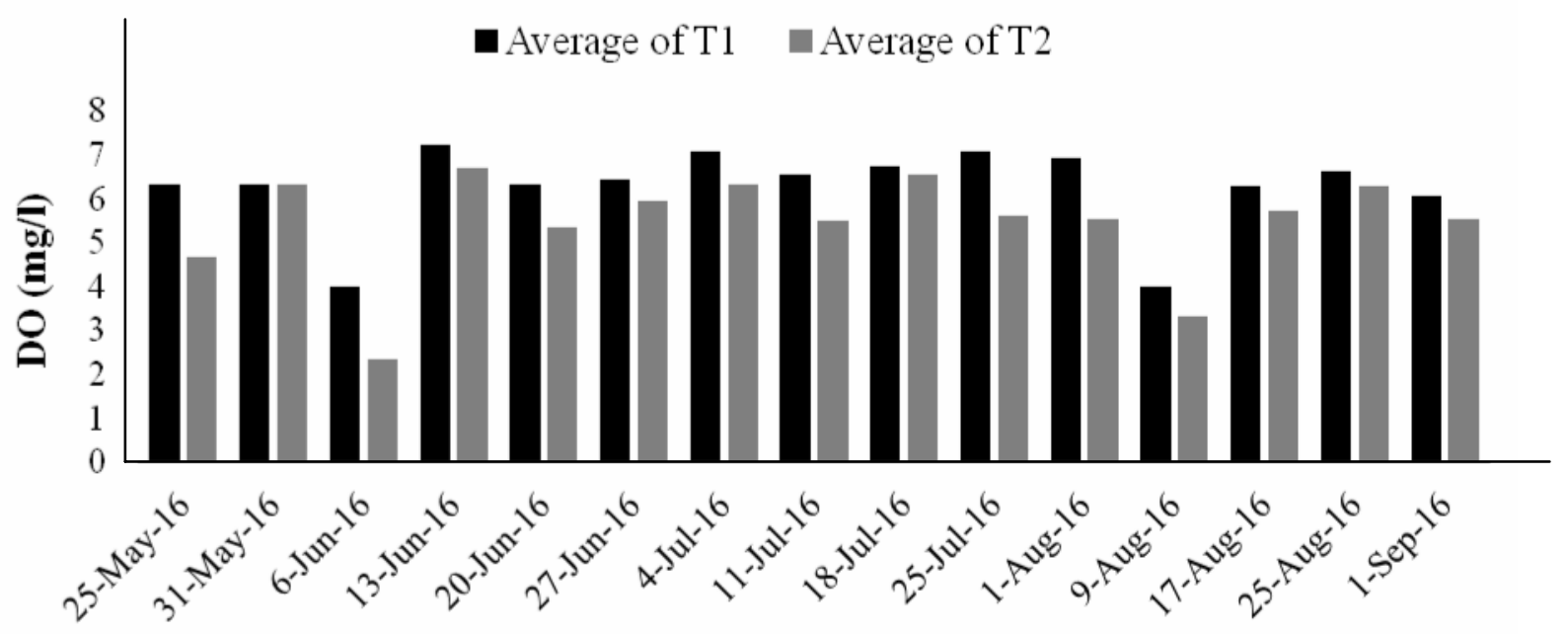

Sampling Date

Fig. 2. Variation of dissolved oxygen between two treatments throughout the study period

\section{Growth performance of fish in different treatments}

The average final lengths of tilapia were $18.50 \pm 1.56 \mathrm{~cm}$ and $17.23 \pm 1.84 \mathrm{~cm}$ in $T_{1}$ and $T_{2}$, respectively where initial average length in both treatments was $2.86 \pm 0.00 \mathrm{~cm}$. Similarly the initial weight of tilapia $(0.40 \pm 0.00)$ increased up to $143.76 \pm 39.33 \mathrm{~g}$ and $111.0 \pm 33.06 \mathrm{~g}$ in $T_{1}$ and $T_{2}$, respectively during final harvest, where mean weight gain were $143.36 \pm 39.33 \mathrm{~g}$ and $110.6 \pm 33.06 \mathrm{~g}$ with significant difference $(p<0.05)$ between $T_{1}$ and $T_{2}$. Moreover, percent weight gain, specific growth rates and production of tilapia were found significantly $(p<0.05)$ higher in $T_{1}$ compared to $T_{2}$ (Table 1 ).

Table 1. Growth performance (mean \pm SD) of tilapia in the experimental ponds

\begin{tabular}{|c|c|c|c|}
\hline \multirow{2}{*}{$\begin{array}{c}\text { Growth parameters of } \\
\text { tilapia }\end{array}$} & \multicolumn{2}{|c|}{ Treatments } & \multirow{2}{*}{$\begin{array}{l}\text { T-test p- } \\
\text { value }\end{array}$} \\
\hline & $\mathrm{T}_{1}$ (Aerated) & $\mathrm{T}_{2}$ (Non-aerated) & \\
\hline Final length $(\mathrm{cm})$ & $18.50 \pm 1.56$ & $17.23 \pm 1.84$ & $0.005^{*}$ \\
\hline Final weight (g) & $143.76 \pm 39.33$ & $111.0 \pm 33.06$ & $0.001^{*}$ \\
\hline Weight gain (g) & $143.36 \pm 39.33$ & $110.6 \pm 33.06$ & $0.000^{*}$ \\
\hline$\%$ weight gain & $35842.5 \pm 0.00$ & $27650 \pm 0.00$ & $0.000^{*}$ \\
\hline $\begin{array}{l}\text { Specific growth rate } \\
\text { (SGR \% per day) }\end{array}$ & $2.54 \pm 0.00$ & $2.42 \pm 0.00$ & $0.000^{*}$ \\
\hline $\begin{array}{l}\text { Production (kg/ha/100 } \\
\text { days) }\end{array}$ & $9581.87 \pm 0.00$ & $6490.80 \pm 0.00$ & $0.000^{*}$ \\
\hline
\end{tabular}

*indicates significant difference between $T_{1}$ and $T_{2}$ at $p<0.05$.

\section{Physico-chemical parameters of water}

Water quality is determined by various physico-chemical and biological factors, as they may directly or indirectly affect its quality and consequently its solubility for the distribution and production of fish and other aquatic animals (Moses, 1983). The mean values of tested water quality parameters such as temperature, $\mathrm{pH}$, ammonia and nitrite of the experimental ponds are presented in Table 2 where water temperature, $\mathrm{pH}$ were slightly higher but ammonia and nitrite level were found lower in aerated ponds $\left(\mathrm{T}_{1}\right)$ compared to non-aerated ponds $\left(T_{2}\right)$. Various water quality parameters were not significantly $(p>0.05)$ differed between $T_{1}$ and $T_{2}$. 
Table 2. Various physico-chemical parameters of water (mean \pm SD) in two different treatments

\begin{tabular}{c|c|c|c|c}
\hline Treatments & Temperature $\left({ }^{\circ} \mathbf{C}\right)$ & $\mathbf{p H}$ & Ammonia (mg/l) & Nitrite (mg/l) \\
\hline $\mathrm{T}_{1}$ & $30.00 \pm 1.44$ & $7.61 \pm 0.26$ & $0.01 \pm 0.01$ & $0.016 \pm 0.028$ \\
$\mathrm{~T}_{2}$ & $30.24 \pm 1.30$ & $7.43 \pm 0.28$ & $0.13 \pm 0.030$ & $0.044 \pm 0.048$ \\
\hline
\end{tabular}

\section{Abundance of plankton}

About 27 genera of phytoplankton were identified of which 6 were belonged to Bacillariophyceae, 14 to Chlorophyceae, 2 to Euglenophyceae, 1 to Rhodophyceae and 4 to Cyanophyceae in present study. Moreover, about 8 genera of zooplankton were identified from the present study of which 2 were belonged to Copepoda, 4 to Rotifera and 2 to Cladocera (Table 3). No significant ( $p>0.05)$ differences were found between $T_{1}$ and $T_{2}$ for the abundance of both phytoplankton and zooplankton in the present study, however the abundance of phytoplankton was higher in $\mathrm{T}_{2}$ and abundance of zooplankton was higher in $\mathrm{T}_{1}$ (Table 4).

Table 3. Generic status of plankton under different major groups found in the aquaculture ponds during the experimental periods

\begin{tabular}{|c|c|c|}
\hline \multirow{2}{*}{ Major groups } & $\mathbf{T}_{1}$ & $\mathbf{T}_{2}$ \\
\hline & \multicolumn{2}{|c|}{ Generic name of phytoplankton } \\
\hline \multirow{14}{*}{ Chlorophyceae } & Actinestrum & Actinistrum \\
\hline & Ankistrodesmus & Ankistrodesmus \\
\hline & Chlorella & Chlorella \\
\hline & Pediastrum & Closterium \\
\hline & Scenedesmus & Crucigenia \\
\hline & Tetraedon & Pleorococcus \\
\hline & Stichococcus & Pediastrum \\
\hline & Ulothrix & Scenedesmus \\
\hline & Closterium & Tetraedon \\
\hline & Crucigenia & Stichococcus \\
\hline & & Ulothrix \\
\hline & & Uroglena \\
\hline & & Spirogyra \\
\hline & & Volvox \\
\hline \multirow{4}{*}{ Cyanophyceae } & Anabaena & Anabaena \\
\hline & Microcystis & Microcystis \\
\hline & Oscillatoria & Oscillatoria \\
\hline & & Spirulina \\
\hline \multirow{6}{*}{ Bacillariophyceae } & Cosmarium & Cosmarium \\
\hline & Fragillaria & Cyclotella \\
\hline & Navicula & Fragillaria \\
\hline & Nitzschia & Navicula \\
\hline & Surilella & Nitzschia \\
\hline & & Surilella \\
\hline \multirow{2}{*}{ Euglenophyceae } & Euglena & Euglena \\
\hline & Phacus & Phacus \\
\hline Rhodophyceae & Hildenbrandia & Hildenbrandia \\
\hline Major groups & \multicolumn{2}{|c|}{ Generic name of zooplankton } \\
\hline \multirow{2}{*}{ Copepoda } & Cyclops & Cyclops \\
\hline & Diaptomus & \\
\hline \multirow{4}{*}{ Rotifera } & Asplanchna & Asplanchna \\
\hline & Brachionus & Brachionus \\
\hline & Polyarthra & Polyarthra \\
\hline & Trichocera & \\
\hline Cladocera & $\begin{array}{c}\text { Daphnia } \\
\text { Diaphanosoma }\end{array}$ & - \\
\hline
\end{tabular}


Table 4. Variations in mean abundance of total phytoplankton $\left(\times 10^{5}\right.$ cells/L) and zooplankton $\left(\times 10^{3}\right.$ cells/ $L$ ) in the experimental ponds under two treatments during the study period

\begin{tabular}{|c|c|c|c|}
\hline \multirow{2}{*}{$\begin{array}{c}\text { Mean ( } \pm \text { SD) abundance of } \\
\text { plankton }\end{array}$} & \multirow[t]{2}{*}{ Treatments } & \multicolumn{2}{|c|}{ Samplings } \\
\hline & & Initial & Final \\
\hline Phytoplankton (cells/L) & $\begin{array}{l}\mathrm{T}_{1} \\
\mathrm{~T}_{2}\end{array}$ & $\begin{array}{l}26.1 \times 10^{5} \pm 22.7 \times 10^{5} \\
34.0 \times 10^{5} \pm 25.2 \times 10^{4}\end{array}$ & $\begin{array}{l}26.5 \times 10^{5} \pm 22.8 \times 10^{5} \\
36.2 \times 10^{5} \pm 19.5 \times 10^{5}\end{array}$ \\
\hline Zooplankton (cells/L) & $\begin{array}{l}\mathrm{T}_{1} \\
\mathrm{~T}_{2}\end{array}$ & $\begin{array}{c}23.3 \times 10^{3} \pm 25.1 \times 10^{3} \\
6.6 \times 10^{3} \pm 11.5 \times 10^{3} \\
\end{array}$ & $\begin{array}{l}30.0 \times 10^{3} \pm 17.3 \times 10^{3} \\
13.3 \times 10^{3} \pm 11.5 \times 10^{3}\end{array}$ \\
\hline
\end{tabular}

\section{Chemical parameters of pond bottom soil (sediments)}

Different chemical parameters of pond bottom soil such as, soil $\mathrm{pH}$, organic matter, total nitrogen, available phosphorus were found within suitable range for aquaculture with no significant differences $(p>0.05)$ between two treatments. Conversely available potassium content was found much lower than optimum range for aquaculture in the ponds of both treatments. Mean values of various chemical parameters of pond bottom soil are presented in Table 5.

Table 5. Various chemical parameters (mean \pm SD) of pond bottom soil in the experimental ponds

\begin{tabular}{c|c|c|c|c|c}
\hline Treatments & Soil pH & $\begin{array}{c}\text { Organic matter } \\
\mathbf{( \% )}\end{array}$ & $\begin{array}{c}\text { Total nitrogen } \\
\mathbf{( \% )}\end{array}$ & $\begin{array}{c}\text { Available } \\
\text { phosphorus (ppm) }\end{array}$ & $\begin{array}{c}\text { Available } \\
\text { potassium (ppm) }\end{array}$ \\
\hline $\mathrm{T}_{1}$ & $6.75 \pm 0.15$ & $2.05 \pm 0.43$ & $0.12 \pm 0.02$ & $15.32 \pm 2.95$ & $87.81 \pm 22.50$ \\
$\mathrm{~T}_{2}$ & $6.79 \pm 0.13$ & $1.94 \pm 0.31$ & $0.10 \pm 0.01$ & $9.64 \pm 3.77$ & $65.00 \pm 10.81$ \\
\hline
\end{tabular}

\section{Relationship between major water quality and weather parameters}

Correlation-matrix shows a various intrinsic relationships between DO and other water quality and weather parameters (Table 6). A non-significant positive relationship was found between DO and the temperature of pond water and atmosphere. However, it had negative relationships with rainfall, air pressure and humidity. There was a significant $(p<0.05)$ positive relationship between air and pond water temperature. However, the relationships of pond water temperature with rainfall, air pressure and humidity were negative but not statistically significant.

Table 6. Correlation-matrix showing the relationship between dissolved oxygen content of experimental pond water and weather parameters

\begin{tabular}{|c|c|c|c|c|c|c|c|}
\hline & & $\begin{array}{l}\text { Pond water } \\
\text { DO (ppm) }\end{array}$ & $\begin{array}{c}\text { Pond water } \\
\text { temperature } \\
\left({ }^{\circ} \mathrm{C}\right)\end{array}$ & $\begin{array}{c}\text { Air } \\
\text { temperature } \\
\left({ }^{\circ} \mathrm{C}\right)\end{array}$ & $\begin{array}{c}\text { Rainfall } \\
(\mathrm{mm})\end{array}$ & $\begin{array}{c}\text { Air } \\
\text { pressure }\end{array}$ & $\begin{array}{c}\text { Humidity } \\
(\%)\end{array}$ \\
\hline Pond water DO (ppm) & $\begin{array}{l}\text { Pearson Correlation } \\
\text { Sig. (2-tailed) }\end{array}$ & 1 & & & & & \\
\hline \multirow[t]{2}{*}{ Pond water temperature $\left({ }^{\circ} \mathrm{C}\right)$} & Pearson Correlation & 0.649 & 1 & & & & \\
\hline & Sig. (2-tailed) & 0.236 & & & & & \\
\hline \multirow[t]{2}{*}{ Air temperature $\left({ }^{\circ} \mathrm{C}\right)$} & Pearson Correlation & 0.523 & $.892^{*}$ & 1 & & & \\
\hline & Sig. (2-tailed) & 0.366 & 0.042 & & & & \\
\hline \multirow[t]{2}{*}{ Rainfall (mm) } & Pearson Correlation & -0.58 & -0.395 & -0.007 & 1 & & \\
\hline & Sig. (2-tailed) & 0.305 & 0.511 & 0.992 & & & \\
\hline \multirow[t]{2}{*}{ Air pressure } & Pearson Correlation & -0.445 & -0.789 & $-.919^{*}$ & -0.215 & 1 & \\
\hline & Sig. (2-tailed) & 0.453 & 0.113 & 0.027 & 0.729 & & \\
\hline \multirow[t]{2}{*}{ Humidity (\%) } & Pearson Correlation & -0.41 & -0.845 & $-.991^{\star \star}$ & -0.08 & $.902^{\star}$ & 1 \\
\hline & Sig. (2-tailed) & 0.493 & 0.072 & 0.001 & 0.898 & 0.036 & \\
\hline
\end{tabular}




\section{Discussion}

Dissolved oxygen (DO) is one of the most important physico-chemical parameter of water because low DO content adversely affects fish growth, feed utilization and fish even die at this low DO concentration. In the present study, the level of DO in the ponds of $T_{1}$ and $T_{2}$ varied from 4.5 to $8.0 \mathrm{mg} / \mathrm{l}$ and 2.0 to 7.7 $\mathrm{mg} / \mathrm{l}$ which was more or less similar to the result of Qayyum et al. (2005) who recorded DO ranging from 4-9 $\mathrm{mg} / \mathrm{l}$ and 2-8 $\mathrm{mg} / \mathrm{l}$ in aerated and non-aerated ponds, respectively. The higher DO content in the aerated ponds in present study might be due to proper and continuous periodical aeration facilities.

Growth performance of tilapia in terms of length gain, weight gain, percent weight gain, specific growth rate and production were found to be significantly $(p<0.05)$ higher in the ponds of $T_{1}$ compared to $T_{2}$. Conversely FCR in the present study was found lower (1.2) in $T_{1}$ compared to $T_{2}$ (1.7) which was within the expected FCR for tilapia (Watanabe et al., 2002). The higher length and weight gain, specific growth rate, survival rate, production and low FCR obtained in the aerated ponds of present study compared to non-aerated ponds might be due to proper feeding, controlled condition, differences in DO content due to aeration facilities since fish growth, feed efficiency and FCR were affected by DO availability and fish always showed good feed efficiency and low FCR when fed at required DO in water (Bergheim et al., 2006 and Duan et al., 2011).

Water temperature plays a crucial role in regulating the metabolic process of fish (Battes et al, 1979). The water temperature $\left(28-32^{\circ} \mathrm{C}\right)$ of ponds in present study was within the suitable range $\left(26-33^{\circ} \mathrm{C}\right)$ for tilapia culture (Tyson and Simonne, 2014). Moreover, $\mathrm{pH}$ values (7.0-7.9) found in $T_{1}$ and $T_{2}$ were within the tolerable range of tilapia for aquaculture (Chervinski, 1982) and were within the acceptable range of 6.5 to 8.5 required for fish culture (DoF, 1996). In the present study, the ammonia $(0.00-0.09 \mathrm{mg} / \mathrm{l})$ and nitrite contents $(0.00-0.066 \mathrm{mg} / \mathrm{l})$ of pond water were found within desirable range of aquaculture (Bhatnagar and Singh, 2010; Stone and Thomforde, 2004). The higher ammonia and nitrite content in $\mathrm{T}_{2}$ (nonaerated) than $T_{1}$ (aerated) might be due to the aeration system since benefit of aeration is to cycle the ammonia to nitrite faster and nitrite could be readily oxidized to non-toxic nitrates in aerobic condition.

In intensive aquaculture system, high concentrations of nutrients in water column, especially phosphorus, ammonia and nitrate, cause phytoplankton blooms (Gilbert et al., 2001) and deterioration of pond water quality. About 27 genera of phytoplankton were identified in the present study belonging to Bacillariophyceae, Chlorophyceae, Euglenophyceae, Rhodophyceae and Cyanophyceae which were similar to the result of Dewan et al. (1991). Besides, about 8 genera of zooplankton were identified from the ponds of present study belonging to Copepoda, Rotifera and Cladocera which was more or less similar to the results of Rahman and Hussain (2008). There were no significant differences ( $>0.05)$ between two treatments for the abundance of phytoplankton in all the sampling stages of present study, however the abundance was higher in $\mathrm{T}_{2}\left(36.2 \times 10^{5} \pm 19.5 \times 10^{5}\right.$ cells/L) compared to $\mathrm{T}_{1}\left(26.5 \times 10^{5} \pm 22.8 \times 10^{5}\right.$ cells/L). The findings of present study were much higher than the result of Siddika et. al. (2012) and this higher phytoplankton production in present study might be practicing intensive aquaculture with high stocking density and high feeding regime. Moreover, zooplankton abundance was found higher in $T_{1}$ compared to $T_{2}$ and this might be due to aeration facilities in $T_{1}$ because growth of zooplankton was related to optimum DO content and other physico-chemical parameters of water in aerated ponds.

Although no significant differences were found between two treatments for various chemical parameters of pond bottom soil but soil pH (6.68 to 6.88), organic matter content (1.40 to 2.47\%) in present study were within the optimum range for fish culture (Boyd et al., 1994). Moreover, total nitrogen content (0.09 to $0.13 \%$ ) of experimental pond bottom soil indicates higher productivity since IASRI (2015) reported that more than $0.05 \%$ of total nitrogen in pond bottom soil was highly productive and available phosphorus content (9.64 to $19.32 \mathrm{ppm}$ ) in present study indicates moderate to poor productivity of fish culture pond since below $13.0 \mathrm{ppm}$ of available phosphorus in bottom soil have been suggested as the index of poor productivity of fish ponds by Banerjea (1967). But available potassium contents (76.0 to $116.0 \mathrm{ppm}$ ) were much lower than the result of Thakur and Chattopadhyay (2015) who reported available potassium ranging from 187.89 to $301.09 \mathrm{ppm}$ in fish ponds. This lower available potassium content in present study 
may be attributed to the occurrence of poor organic carbon, lighter texture and consequently low cation exchange capacity in the pond soil. These all the soil quality parameters indicate that the increased growth and production of tilapia through applying aeration did not change the pond soil quality.

Meteorology plays an important role in fisheries and aquaculture because solar radiation and air temperature influence water temperature, which in turn affects the natural productivity of inland and marine waters and the growth of fisheries species (Kapetsky, 2000). In the present study, bivariate correlationship showed that DO content increased in pond water with the increase of water and air temperature and DO content decreased with the increase of air pressure. These results were different from the findings of Wurts (2013); Bhatnagar and Devi (2013); and Fondriest (2013). The difference in the result of present study does not have any broader implications as the relationship between the parameters was not statistically significant. Moreover, correlation matrix showed that DO content decreased with the increase of rainfall, air pressure and humidity or vice versa. The result of decreasing DO content with the increase of humidity and rainfall in present study was similar to the findings of (Bhatnagar and Devi, 2013) and Wurts (2013). There was a significant $(p<0.05)$ positive relationship between air and pond water temperature which was similar to the observations of Morrissy (1976) who reported that water temperature in aquaculture ponds closely followed air temperatures.

\section{Conclusion}

Overall, aeration improved DO content in pond water and also showed a difference for water quality parameters between aerated and non-aerated ponds. Along with DO, other water quality parameters such as temperature, $\mathrm{pH}$, nitrite, ammonia in the aerated ponds were within the better range of aquaculture compared to non-aerated ponds. The effect of aeration also showed a significant difference $(p<0.05)$ between two treatments for length gain, weight gain and SGR of tilapia. Moreover, DO content had complex relationships with local weather parameters that means if different weather parameters of locality are known to farmers then farmers will be able to predict the level of water temperature and DO in pond water. Therefore, it can be argued that aeration is a potential mechanism of aqua-farming to enhance growth and production of fish at higher stocking densities. Further action research is required at the field level for building awareness among the farmers on aeration and its impacts on pond productivity.

\section{References}

Abdel-Tawwab, M., Hagras, A.E., Elbaghdady, H.A.M. and Monier, M.N. 2014. Dissolved oxygen level and stocking density effects on growth, feed utilization, physiology and innate immunity of Nile tilapia, Oreochromis niloticus. Journal of Applied Aquaculture, 26(4): 340-355.

Agarwal, V.P. 1999. Recent Trends in Aquaculture. Agarwal Printers, 1174, P. Sharma Road, Meerut. pp. 550-556.

Banerjea, S.M. 1967. Water quality and soil condition of fish ponds in some states of India in relation to fish production. Indian Journal of Fisheries, 14: 115-144.

Battes, K., Constania, L., Valencive, N., Lordache, L. and Tarus, T. 1979. Carp culture in floating cages. Bulletin of Correct piscis, 1(1-2): 68-95

Bergheim, A., Gausen, M., Naess, A., Holland, P.M., Krogedal, P. and Crampton, V. 2006. A newly developed oxygen injection system for cage farms. Aquacultural Engineering, 34(1): 40-46.

Bhatnagar, A. and Devi, P. 2013. Water quality guidelines for the management of pond fish culture. International Journal of Environmental Science, 3(6): 1980-2009.

Bhatnagar, A. and Singh, G. 2010. Culture fisheries in village ponds: a multi-location study in Haryana, India. Agriculture and Biology Journal of North America, 1(5): 961-968.

Boyd, C.E. 1995. Potential for sodium nitrate to improve environmental conditions in aquaculture ponds. World Aquaculture, 26(2): 38-39.

Boyd, C.E. 1998. Pond water aeration systems. Aquacultural Engineering, 18: 9-40.

Boyd, C.E., Tanner, M.E., Madkour, M. and Masuda, K. 1994. Chemical characteristics of bottom soils from freshwater and brackishwater aquaculture ponds. Journal of the World Aquaculture Society, 25(4): 517-534.

Chervinski, J. 1982. Environmental physiology of tilapia. In: Pullin RSV, Lowe McConnel RH (Editors), The Biology and Culture of Tilapia. ICLARM Conference Proceedings 7. Manila, Philippines. 119-128 pp.

Cooke, G.D. and Kennedy, R.H. 2001. Managing drinking water supplies. Lake and Reservoir Management, 17: 157-174. 
Dewan, S., Wahab, M.A., Beveridage, M.C.M., Rahman, M.H. and Sarker, B.K. 1991. Food selection, electivity and dietary overlap among planktivorous Chinese and Indian major carps fry and fingerlings grown extensively managed rain-fed ponds in Bangladesh Agricultural University, Mymensingh. Bangladesh Journal of Fisheries, 22: 277-294.

DoF, 1996. National Fish Week 1996: Compendium (in Bengali), Department of Fisheries, Ministry of Fisheries and Livestock, Bangladesh. 144 pp.

DoF, 2016. Jatio Matshya Saptaho Shankalan, Department of Fisheries, Ministry of Fisheries and Livestock, Dhaka, Bangladesh. 129-132 pp.

Duan, Y., Dong, X., Zhang, X. and Miao, Z. 2011. Effects of dissolved oxygen concentration and stocking density on the growth, energy budget and body composition of juvenile Japanese flounder, Paralichthys olivaceus (Temminck et Schlegel). Aquaculture Research, 42: 407-416.

FAO, 2016. The State of World Fisheries and Aquaculture, Food and Agriculture Organization of the United Nations, Rome, Italy, 2016.

Fondriest Environmental, 2013. Dissolved Oxygen: Fundamentals of Environmental Measurements. http://www.fondriest.com/ environmentalmeasurements/parameters/water-quality/dissolved-oxygen, Date of Access- 10 October 2016.

Gilbert, P.M., Magnien, R., Lomas, M.W., Alexander, J., Fan, C., Haramoto, E., Trice, M. and Kana, T.M. 2001. Harmful algal blooms in the Chesapeake and coastal bays of Maryland USA: comparison of 1991, 1998, and 1999 events. Estuaries, 24: 875-883.

Grizzell, R.A., Dillon, O.W. and Sullivan, E.G. 1969. Catfish farming: a new crop. United States. Department of Agriculture, Farmers Bulletin 2244. Washington, USA.

IASRI, 2015. Soil and Water Quality Criteria; Requirements for Aquaculture. http://ecoursesonline.iasri.res.in/mod/ resource/ view.php?id=86319, Date of Access- 18 November 2016.

Kapetsky, J.M. 2000. Present applications and future needs of meteorological and climatological data in inland fisheries and aquaculture. Agricultural and Forest Meteorology, 103: 109-117.

Le Jeune, A.H., Charpin, M., Deluchat, V., Briand, J.F., Lenain, J.F., Baudu, M. and Amblard, C. 2006. Effect of copper sulphate treatment on natural phytoplanktonic communities. Aquatic Toxicology, 80: 267-280.

Mallya, Y.J. 2007. The effects of dissolved oxygen on fish growth in aquaculture. United Nations University, Fisheries Training Programme, UNU-FTP. $30 \mathrm{pp}$.

Mayer, K.E. and Eschmeyer, P.T. 1973. Second Report to fish farmers. Bureau of Sport Fisheries and Wildlife Resources Publication 113, Washington, USA.

Morrissy, N.M. 1976. Aquaculture of marron, Cherax tenuimanus (Smith). Part 1. Site selection and the potential of marron for aquaculture. Fisheries Research Bulletin, Western Australia, 17: 1-27.

Moses, B.S. 1983. Introduction to tropical fisheries, Ibadan University Press, UNESCO/ICSU, Part. 102-105 pp.

Qayyum, A., Ayub, M. and Tabinda, A.B. 2005. Effect of aeration on water quality, fish growth and survival in aquaculture ponds. Pakistan Journal of Zoology, 37(4): 75-80.

Rahman, M.S. 1992. Water quality management in aquaculture. BRAC Prokashona, Dhaka. 84 pp.

Rahman, S. and Hussain, M.A. 2008. A study on the abundance of zooplankton of a culture and a non-culture pond of the Rajshahi University campus. University Journal of Zoology, 27: 35-41.

Siddika, F., Shahjahan, M. and Rahman, M.S. 2012. Abundance of plankton population densities in relation to bottom soil textural types in aquaculture ponds. International Journal of Agricultural Research, Innovation and Technology, 2(1): 56-61.

Stone, N.M. and Thomforde, H.K. 2004. Understanding Your Fish Pond Water Analysis Report. Cooperative Extension Programme, University of Arkansas at Pine Bluff Aquaculture / Fisheries.

Swingle, H.G. 1968. Fish kills caused by phytoplankton blooms and their prevention. Food and Agriculture Organization of the United Nation Fisheries Report, 44: 407-411.

Thakur, M. and Chattopadhyay, G.N. 2015. Soil and water qualities influencing productivity of fish ponds of different soil zones of West Bengal. International Journal of Plant, Animal and Environmental Sciences, 5(1): 74-79.

Tyson, R.V. and Simonne, E.H. 2014. A practical guide for aquaponics as an alternative enterprise. University of Florida Horticultural Science Department, UF/IFAS Extension document HS1252.

Watanabe, W.O., Losordo, T.M., Fitzsimmons, K. and Hanley, F. 2002. Tilapia production systems in the Americas: technical advances, trends and challenges. Reviews in Fisheries Science, 10(3-4): 465-498.

Wurts, W.A. (2013): Low oxygen and pond aeration. www.ca.uky.edu/wkrec/Wurtspage.htm,_Date of Access-10 October 2016. 